\title{
INTERNAL FEATURES OF THE EMBRYONIC SHELLS OF AMMONOIDS AS EXPOSED IN WELL PRESERVED SPECIMENS
}

LANDMAN, Neil H., Amer. Mus. Nat. Hist., 79th St. and Cent. Pk. W., New York, NY 10024, U.S.A.; MAPES", Royal H., Dept. Geol., Univ. Ohio, Athens, OH 45701, U.S.A.; TANABE, Kazushige, Geol. Inst., Univ. Tokyo, Tokyo 113, Japan; KLOFAK, Susan M., Amer. Mus. Nat. Hist., 79th St. and Cent. Pk. W., New York, NY 10024 and City College and Grad. School, CUNY, U.S.A.

Well-preserved ammonoid specimens without any interior matrix permit a three dimensional view of the internal features of the embryonic shell. We present scanning electron micrographs of specimens representing four ammonoid suborders. 1) Agoniatitina. In a specimen of Agoniatites sp. from the Middle Devonian of North Africa differential weathering has exposed the caecum and prosiphon, both of which occur in the initial chamber at some distance from the proseptum. 2) Goniatitina. In a specimen of Glaphyrites sp. from the Upper Carboniferous of Oklahoma, the caecum and prosiphon are visible in the initial chamber immediately adapical of the proseptum. There is a single, elongate muscle scar on the inside surface of the flange. A ridge appears along the ventral margin of the proseptum on its adapical side. The proseptum has a short septal neck that is directed both adorally and adapically. 3) Ammonitina. Several specimens of Quenstedtoceras sp. from the Middle Jurassic of Poland show the interior of the initial chamber with the caecum, prosiphon, and proseptum. A prismatic ridge occurs at the attachment of the proseptum to the wall of the initial chamber. There is a pair of muscle scars in the second chamber on either side of the proseptal opening. An elongate muscle scar occurs in the third chamber above the siphuncle. All subsequent scars are ovoid and occur adoral of the dorsal lobes. 4) Ancyloceratina. In several specimens of Baculites sp. from the Upper Cretaceous of Wyoming, the initial chamber and proseptum are well exposed. Wrinkles occur on the lateral lobes of the proseptum and on its extension below the flange. A ridge is present at the attachment of the proseptum to the initial chamber wall. We suggest that the presence of such features as the muscle scar along the inside surface of the flange and the ridge at the base of the proseptum in several ammonoid suborders may indicate similarities in embryonic development among these diverse forms. 